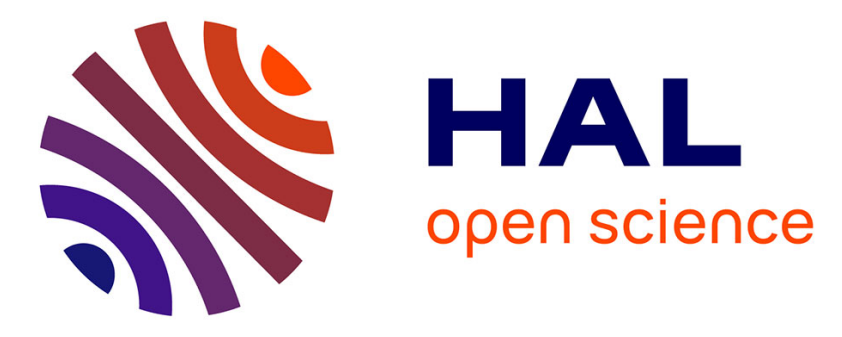

\title{
Parental age does not influence offspring telomeres during early life in common gulls ( Larus canus )
}

Tuul Sepp, Richard Meitern, Britt Heidinger, Kristina Noreikiene, Kalev

Rattiste, Peeter Hõrak, Lauri Saks, Jeffrey Kittilson, Janek Urvik, Mathieu

Giraudeau

\section{To cite this version:}

Tuul Sepp, Richard Meitern, Britt Heidinger, Kristina Noreikiene, Kalev Rattiste, et al.. Parental age does not influence offspring telomeres during early life in common gulls ( Larus canus ). Molecular Ecology, 2021, 10.1111/mec.15905 . hal-03418462

\section{HAL Id: hal-03418462 \\ https://hal.science/hal-03418462}

Submitted on 7 Nov 2021

HAL is a multi-disciplinary open access archive for the deposit and dissemination of scientific research documents, whether they are published or not. The documents may come from teaching and research institutions in France or abroad, or from public or private research centers.
L'archive ouverte pluridisciplinaire HAL, est destinée au dépôt et à la diffusion de documents scientifiques de niveau recherche, publiés ou non, émanant des établissements d'enseignement et de recherche français ou étrangers, des laboratoires publics ou privés. 
1

$4 \quad$ Running title: Parental age and telomeres in common gulls

5

6 Tuul Sepp ${ }^{\mathrm{a} \# *}$, Richard Meitern ${ }^{\mathrm{a} \#}$, Britt Heidinger ${ }^{\mathrm{b}}$, Kristina Noreikiene ${ }^{\mathrm{c}}$, Kalev Rattiste ${ }^{\mathrm{d}}$,

7 Peeter Hõrak ${ }^{\mathrm{a}}$, Lauri Saks $^{\mathrm{e}}$, Jeffrey Kittilson $^{\mathrm{b}}$, Janek Urvik $^{\text {af\# }}$, Mathieu Giraudeau ${ }^{\mathrm{g} \#}$

8

$9{ }^{a}$ Institute of Ecology and Earth Sciences, University of Tartu, Vanemuise 46, 51014 Tartu, 10 Estonia

$11{ }^{b}$ Biological Sciences Department, North Dakota State University, Stevens Hall, Fargo, ND $1258108, U S A$

$13{ }^{c}$ Institute of Veterinary Medicine, Estonian University of Life Sciences, Kreutzwaldi 62, 51006

14 Tartu, Estonia

$15{ }^{d}$ Institute of Agricultural and Environmental Sciences, Estonian University of Life Sciences, 16 Kreutzwaldi 1, 51006 Tartu, Estonia

$17{ }^{e}$ Estonian Marine Institute, University of Tartu, Vanemuise 46a, 51014, Tartu, Estonia

$18{ }^{f}$ Institute of Biomedicine and Translational Medicine, University of Tartu, Ravila 19, 50411, 19 Tartu, Estonia

$20{ }^{g}$ CREEC, 911 Avenue Agropolis, BP 6450134394 Montpellier Cedex 5, France and 21 MIVEGEC,

22 UMR IRD/CNRS/UM 5290, 911 Avenue Agropolis, BP 6450134394 Montpellier Cedex 5, 23 France 
$26 *$ Corresponding author, tuul.sepp@ gmail.com

27 \# these authors contributed equally to the study

28

29 Abstract

30 Parental age can affect offspring telomere length through heritable and epigenetic-like effects, 31 but at what stage during development these effects are established is not well known. To 32 address this, we conducted a cross-fostering experiment in common gulls (Larus canus) that 33 enabled us distinguish between pre- and post-natal parental age effects on offspring telomere 34 length. Whole clutches were exchanged after clutch completion within and between parental 35 age classes (young and old) and blood samples were collected from chicks at hatching and 36 during the fastest growth phase (11 days later) to measure telomeres. Neither the ages of the 37 natal nor the foster parents' predicted the telomere length or the change in telomere lengths of 38 their chicks. Telomere length was repeatable within chicks, but increased across development 39 (repeatability $=0.55$, Intraclass Correlation Coefficient within sampling events 0.934). 40 Telomere length and the change in telomere length were not predicted by post-natal growth 41 rate. Taken together, these findings suggest that in common gulls, telomere length during early 42 life is not influenced by parental age or growth rate, which may indicate that protective 43 mechanisms buffer telomeres from external conditions during development in this relatively 44 long-lived species.

46 Keywords 
47 Ageing, seabirds, telomere length, telomere dynamics, maternal effects, qPCR

49 Introduction

50 Parental age often has long-term effects on offspring phenotype in humans (Carlaske,

51 Tynelius, van den Berg, \& Smith, 2019) and wild animals (Bowers, Sakaluk, \& Thompson,

52 2017). In some cases, increased parental age has a positive long-term effects on offspring

53 (Bradley \& Safran, 2014), possibly because older parents are more experienced breeders than

54 younger parents and/or because reproductive investment increases with age as future

55 reproductive opportunities decline (e.g., terminal investment) (Clutton-Brock, 1984).

56 Alternatively, parental age may have negative long-term effects on offspring if older parents

57 experience senescent declines in condition and/or reproductive function relative to younger

58 parents (Bock, Jarvis, Corey, Stone, \& Gribble, 2019; Maklakov \& Chapman, 2019; Velarde

$59 \&$ Menon, 2016). Regardless, the mechanisms that underlie these long-term effects of parental

60 age on offspring phenotype are not well understood, although several candidate mechanisms

61 have been proposed, including, for example, epigenetic factors (Bock et al. 2019).

62 One of the mechanisms that could mediate trans-generational effects of parental on offspring

63 fitness could be offspring and parental telomere length (TL). Telomeres are highly conserved,

64 repetitive, non-coding sequences of DNA that form protective caps at the ends of

65 chromosomes, thereby enhancing genome stability (Blackburn, 1991). While some evidence

66 suggests that TL is largely inherited (Nordfjäll, Larefalk, Lindgren, Holmberg \& Roos, 2005;

67 Njajou et al., 2007; Olsson et al., 2011, Horn et al., 2011; Reichert et al. 2014), it is also

68 known that TL and telomere dynamics are affected by a complex interaction of genetic effects

69 and environmental factors during an organism's life (Dugdale \& Richardson, 2018; 
70 Monaghan, 2010). While telomeres typically shorten (but sometimes also elongate) with age

71 in somatic cells, elongation of telomeres has also been described, mainly as a result of the

72 activity of the enzyme telomerase, which can extend telomeres via the addition of terminal

73 telomeric repeats (Cong, Wright, \& Shay, 2002), and which is variably active in different cell

74 types and at different life stages, and in different taxonomic groups (Gomes et al. 2011). The

75 effect of parental age on the length of offspring telomeres is currently intensively studied (e.g.

76 Bauch, Boonekamp, Korsten, Mulder,\& Verhulst, 2019; Criscuolo, Zahn,\& Bize, 2017;

77 Heidinger et al. 2016; Froy et al. 2017; Noguera \& Velando, 2020). Costs and benefits

78 associated with maintaining the length of telomeres are particularly interesting when

79 considering the adaptive role of telomeres in the evolution of life histories, as it is suggested

80 that telomeres play a proximate causal role in current-future life-history trade-offs (Young,

81 2018). Optimal life-history strategies are both inherited and shaped by environmental effects

82 (Stearns, 1992), and accordingly, telomere dynamics are a plausible physiological mechanisms

83 related to life-histories (Giraudeau, Angelier, \& Sepp, 2019).

84 While an increasing number of studies indicate parental age effects on offspring telomeres, the

85

86

87 timing of these effects in terms of offspring development is still unknown. There are three potential routes through which parental age could impact offspring telomeres (Haussmann \& Heidinger 2015; Heidinger \& Young, 2020). First, age-associated changes in parental gametes may affect the telomere length of offsprings. Parental age may negatively influence offspring telomere length if older parents produce gametes with shorter telomeres (shown for example in mice, Mus musculus, de Frutos et al. 2015), however, studies in humans have also shown that older fathers may have offspring with longer telomeres (Broer et al. 2013; Unryn, Cook, \& Riabowol, 2005), due to active telomerase in sperm cells (Kimura et al., 2008). Such 
93 inconsistences among studies, but also between species, could stem from differences in life94 history strategies, likely via mechanisms related to spermatogonial stem cell telomere 95 retention with increasing age, or selective attrition/survival of spermatogonia (Kimura et al. 96 2008; Eisenberg \& Kuzawa 2018). Studies in humans have mostly found a link between 97 paternal age and offspring telomere length (Broer et al. 2013; Unryn, Cook, \& Riabowol, 98 2005), however, the effect of maternal age has been shown to be even stronger than paternal 99 age for some species (e.g. great reed warbler Acrocephalus arundinaceus, Asghar, Bensch, 100 Tarka, Hansson, \& Hasselquist, 2015). While maternal reproductive cells develop at a very 101 early age, after which they are retained throughout life without further cell divisions, 102 association between mother age and offspring telomere length could be explained by other 103 mechanisms, for example age- and/or condition-dependent telomerase activity in the ovaries 104 (Asghar et al. 2015a; Kinugawa, Murakami, Okamura, \& Yajima, 2000). Second possible 105 route is through pre-natal effects, for example age-associated changes in the amounts of 106 glucocorticoid or androgen hormones transferred from the mother to the developing embryo 107 with increasing age of the mother (Haussmann \& Heidinger, 2015; Heidinger \& Young, 2020; 108 Stier, Metcalfe, \& Monaghan 2019). This could in turn activate the production of reactive 109 oxygen species (ROS), as well as decrease telomerase activity in the offspring (Haussmann \& 110 Heidinger, 2015), potentially leading to telomere erosion. While there are now a number of 111 studies linking pre-natal stress to offspring telomeres (reviewed for example, in Dantzer et al. 112 2020; Haussmann \& Heidinger; 2015, Heidinger \& Young, 2020), none have included 113 parental age in this equation. Third route are post-natal effects, as age-related variation in 114 parental care and the characteristics of the post-birth environment could also be important 115 mediators of offspring telomere dynamics (Tarry-Adkins et al. 2009). For example, more 
experienced parents may provide better care (Beamonte-Barrientos, Velando, Drummond, \&

117 Torres, 2010), but older parents may also become less capable of providing a high quality 118 environment due to senescence effects (Torres, Drummond, \& Velando, 2011). The quality of 119 the parental care during the growth phase may hasten or reduce telomere shortening 120 (Criscuolo et al., 2017) with long-lasting effects on the aging rate and life-history trajectories 121 of the offsprings (Young 2018).

122 Distinguishing between the role of genetic/pre-natal and post-natal effects on telomere length 123 and telomere dynamics in natural populations early in life is difficult, but potentially most 124 important from an evolutionary and ecological perspective (Dugdale \& Richardson, 2018). 125 Birds are a promising model system for this kind of study, as the embryo development takes 126 place within a sealed system, the egg, limiting the physiological maternal effects with the 127 moment of egg laying. Cross-fostering experiments are a useful tool, as they allow to tease 128 apart effects that are epigenetic and/or due to pre-natal egg effects, from effects occuring 129 during incubation and/or chick feeding. However, to the best of our knowledge, there are only 130 two studies that have used cross-fostering approach to separate the genetic and environmental 131 effects of parental age on offspring telomere length. In alpine swifts (Apus melba), foster 132 mother's age negatively affected offspring telomere length (Criscuolo et al., 2017). Bauch et 133 al. (2019) showed that paternal age effect on offspring telomere length is independent of 134 paternal care after conception in jackdaws (Corvus monedula). However, neither of these 135 studies took repeated measures during chick growth. Measuring chicks repeatedly allows to 136 assess the change in TL during growth and to separate phenotypic variance into individual and 137 residual variance components to calculate repeatability (Stoffel, Nakagawa, \& Schielzeth, 138 2017). In a recent cross-fostering study of king penguins (Aptenodytes patagonicus), repeated 
measures of TL were taken, indicating that chick telomere length was positively related to foster mothers' TL at both 10 and 105 days after hatching, however, this study did not include information about parental age (Viblanc et al 2020). Our study combines both of these approaches, applying a cross-fostering manipulation between differently aged parents with repeated measures of offspring telomere length in a wild population of long-lived birds. We cross-fostered whole clutches of common gull (Larus canus) eggs shortly after laying within and between age classes of young and old parents, and assessed telomere length and dynamics during the chick fastest growth phase (from hatching to approximately two weeks old), based on blood samples. This time period was based on the feasibility of repeated trapping of precocial bird chicks. The red blood cells (a major component of the blood) of birds have a maximum lifespan of about 30-40 days (Rodnan et al., 1957), and accordingly, it is reasonable to expect to see an effect on telomere shortening in this time period. We predicted that if there are pre-natal, epigenetic-like effects of parental age on offspring telomeres, there will be a relationship between the age of the natal parent and offspring telomeres, but if post-natal, environmental effects mediate the link between parental age and offspring telomere length, there will be a relationship between the age of the foster parent and offspring telomeres.

\section{Materials and methods}

\section{Field methods.}

We conducted the study between the end of May - early June 2017 on a free-living, knownage breeding population of common gulls located on Kakrarahu islet in Matsalu National Park on the west coast of Estonia $\left(58^{\circ} 46^{\prime} \mathrm{N}, 23^{\circ} 26^{\prime} \mathrm{E}\right)^{34}$. Based on studies of offspring recruitment rate, reproductive success in common gulls increases to the 10th breeding year (12-13 years of 
162 age) and decreases thereafter (Rattiste, 2004). It is known that they undergo senescence in a 163 number of physiological functions (Rattiste et al. 2015; Sepp et al. 2017; Urvik, Rattiste, 164 Giraudeau, Okuliarová, Hõrak \& Sepp, 2018). In addition, this species is characterized by bi165 parental care and a low frequency of extra-pair mating (Bukacinska, Bukacinski, Epplen,, 166 Sauer, \& Lubjuhn, 1998), making it possible to study the effects of age of the parent of both 167 sexes, and the age-dependent quality of parental care. All of the birds included in the study 168 were banded as chicks and their exact age was therefore known. Common gulls typically lay 169 clutches of three eggs, independent of maternal age.

170 A total of 40 clutch nests were included in the experiment. Nests and experimental groups 171 were chosen based on the age of the mother, but the father's age was also known. Common 172 gulls mates assortatively with respect to age and the ages of the parents were highly positively 173 correlated (Spearman $\mathrm{r}=0.74, \mathrm{p}<0.0001)$ Half of the breeders $(n=20$ females) were young, on 174 their 1 st-3rd breeding event (age exactly 5 years). Another half ( $n=20$ females) were middle175 aged or older (15-30 years old, average age $18 \pm 3.37$ (SD) years). In total, 19 males were 5-7 176 years old (average age $5.52 \pm 0.80(\mathrm{SD})$ years) and were grouped as "young", 21 males were $17710+$ years (average age $16.29 \pm 5.58(\mathrm{SD})$ years) old and were grouped as "old". Distribution 178 of the ages of parent birds are shown in figures S4-S7.

179 We cross-fostered whole clutches right after the clutch was completed both within and 180 between maternal age classes (Table 1), so all of the chicks included in this experiment 181 hatched in foster-parent's nests. Half of the clutches were cross-fostered between age classes 182 (to test for the effects of parental age - young vs old - on offspring telomere length) and half 183 of the clutches within age classes (to exclude the possibility that we are measuring the effect 184 of cross-fostering). We opted for cross-fostering whole clutches instead of a split-nest design 
185 for the following reasons. (1.) Swapping half clutches would have required very careful and 186 logistically complicated monitoring of hatching order within nests, to know which chick 187 hatched from which egg. (2.) Swapping part of the clutch would have required very careful 188 189 timing with each two nests exactly on the same breeding schedule, to avoid age differences between „own“ and „foster“ chicks. (3.) In case of split-nest cross-fostering with a 3-egg clutch, if one of the chicks dies, the nest is lost for the analysis. (4) A split-nest design with a 3-egg clutch would reduce the robustness and power with the relatively few clutches available. (5) Since the main approach was to swap between parental age categories, cross-fostering whole clutches was a feasible study design. The 72 chicks that were successfully caught for second sampling were included in the study. From the nests of "old" parents, we recaptured on average 1.6 chicks, from "young" parents, 2.0 chicks ( $t$-test $t=-1.7, p=0.1$ ). Within two days from hatching, we collected the first blood sample (10-30 $\mu \mathrm{L}$ taken, from brachial vein) for telomere measurement (average age $0.61 \pm 0.09$ (SE) days) and individually marked the chicks for identification. Chick head size (the distance from the tip of the bill to the back of the head) was measured with a calliper to the nearest $0.1 \mathrm{~mm}$. The day of the second blood sample varied between chicks, due to difficulties in trapping precocial chicks. We captured the chicks near their nests and collected a second blood sample between the 8th and 20th day after hatching (with one exception of a 5-days old chick). Average age at second blood sampling was 10.62 days $( \pm 0.35 \mathrm{SE})$. Blood samples were kept on ice in an insulated box while on the islet, and stored at $-20^{\circ} \mathrm{C}$ until the end of the field work period, when they were transferred to $80^{\circ} \mathrm{C}$ and held there until analysed. The experimental protocol was approved by the Ministry of Rural Affairs of the Republic of Estonia (licence no. 106, issued 24.05.2017) and was performed in accordance with relevant Estonian and European guidelines and regulations. 


\section{Telomere measurement methods and molecular sexing}

210 DNA was extracted from whole blood samples using Macherey Nagel Nucleospin Blood kits

211 following the manufacturer's protocol. Avian red blood cells are nucleated and are well suited

212 for longitudinal telomere analysis (Nussey et al. 2014). DNA concentration and purity were

213 assessed with a Nanodrop 8000 (Thermo Scientific), all our samples had high purity. Relative

214 telomere length was measured using qPCR (quantitative polymerase chain reaction) on an

215 Mx3000P (Stratagene) as described in Cawthon (2002) and modified for use in common gulls

216 (Rattiste et al., 2015). The relative telomere length (T/S) of the samples was calculated as the

217 ratio of the telomere repeat copy number (T) to that of a single copy control gene (S), relative

218 to the reference sample. Glyceraldehyde-3-phosphate dehydrogenase (GAPDH) was used as

219 the single copy control gene. We used the following gull specific GAPDH forward and reverse

220 primers (Integrated DNA Technologies): 5'-CGGAGCACCGCTTACAATTT-3' and 5'-

221 GCATCTCCCCACTTGATGTTG-3' respectively (concentration in reaction mixture 200

$222 \mathrm{nM})$. Amplified samples were run on a 3\% agarose gel to verify that the amplification was a

223 single product, which yielded a single band at $77 \mathrm{bp}$ as expected. We used the following

224 telomere primers (Quanta Bio, with final concentration of $200 \mathrm{nM}$ ): TEL 1b: 5'-

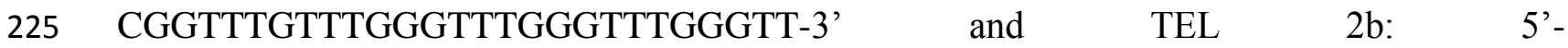

226 GGCTTGCCTTACCCTTACCCTTACCCT-3. The qPCR reactions for GAPDH and

227 telomeres were run on separate plates. The cycling parameters for telomere plate were 228 following: 1 cycle $-10 \mathrm{~min}$ at $95^{\circ} \mathrm{C}, 27$ cycles $-15 \mathrm{sec}$ at $95^{\circ} \mathrm{C}, 30 \mathrm{sec}$ at $58^{\circ} \mathrm{C}, 30 \mathrm{sec}$ at $72^{\circ} \mathrm{C}$,

2291 cycle of dissociation curve (melt curve). The cycling parameters for the GAPDH plate were 230 following: 1 cycle $-10 \mathrm{~min}$ at $95^{\circ} \mathrm{C}, 40$ cycles $-30 \mathrm{sec}$ at $95^{\circ} \mathrm{C}, 30 \mathrm{sec}$ at $60^{\circ} \mathrm{C}, 1 \mathrm{cycle}$ of 
231 dissociation curve (melt curve). All reactions used $20 \mathrm{ng}$ of DNA in a final volume of $25 \mu 1$ 232 containing $12.5 \mu \mathrm{l}$ of SYBR green Master Mix, $0.25 \mu 1$ forward and reverse primer, $6 \mu 1$ 233 water, and $6 \mu \mathrm{l}$ of DNA sample. A negative control of water was run on each plate. All 234 samples were run in duplicate, and average values were used to determine the T/S ratio. 235 Treatment groups were distributed approximately equally between plates. Technical replicates 236 of each sample, and the first and second sample for each bird were run on the same plate. 237 Duplicates that had a SD higher of 0.25 were rerun again as duplicates. In order to assess the 238 efficiencies of each plate, samples were run against a standard curve of 40, 20, 10, 5, and 2.5 239 ng produced by serially diluting a reference sample. In all cases, plate efficiencies were in the 240 accepted range (i.e. 100+/-15\%) and all of the samples fell within the bounds of the standard 241 curve. Average plate efficiencies and standard errors for GAPDH and telomere plates were $242102.34 \pm 3.00$, and $98.94 \pm 3.00$, respectively. The average intra-plate variation of the $\mathrm{Ct}$ 243 values was $0.82 \%$ for the telomere assays and $0.19 \%$ for the GAPDH assays, and the inter244 plate $\mathrm{CV}$-s of the $\mathrm{Ct}$ values for telomere and GAPDH assays were $0.64 \%$ and $0.34 \%$, 245 respectively. The same individual was also included on every plate and the coefficient of 246 variation of the T/S ratio across plates was 8.12\%. Standards and Golden (reference sample) 247 were from birds not included in the experiment. A subset of samples (45) was ran twice for 248 assessing measurement accuracy. Average Intraclass Correlation Coefficient (ICC) in this 249 subset was $0.934(95 \%$ CI $0.879 \pm 0.964), \mathrm{p}<0.0001$, for single measurements $\mathrm{ICC}=0.876$ $250 \quad(95 \%$ CI $0.785 \pm 0.930) \mathrm{p}<0.0001$.

251 The CHD gene (Chromo Helicase DNA-binding gene) was use as a molecular marker for 252 sexing the birds. PCR was used to amplify the CHD genes in DNA extracted from the red 253 blood cells. The primers used in the PCR were as follows: 2550F (5'- 

described by Fridolfsson and Ellergen (1999). The PCR products were visualized by gel electrophoresis and a FluorChem FC2 imaging system. One band on the gel indicates a male

257 and two bands indicates a female.

\section{Statistical methods}

To test for an effect of parental age on chicks' telomere erosion and telomere measurements at

261 first and second sampling, we used repeated measures mixed models and the $\mathrm{R}$ package lmerTest (Kuznetsova, Brockhoff \& Christensen, 2017). Brood ID and the sex of the chick were included as a random effect in our analysis to account for the common origin of the 264 chicks originating from the same brood. Models included age groups (young or old) of either mother and foster mother or father and foster father as categorical predictors, to emphasize our

266 study design and questions. Similar models were also run with age as a continuous factor 267 (Table S1). Separate models were run for mother's and father's age effect, since the age of 268 parents was strongly correlated and could not be entered in the same models. Both models with and without interaction (Tables 2 and S2) with sampling occasion (first or second) were run. Interval between sampling varied between individuals, but this was not included in these

271 models as it was not related to telomere length (Figure S8, Table S6, p = 0.805). Parental age 272 effect models were run for head size as a dependent variable (Tables S4-S5). In these models, 273 chick age was included as a predictive factor since it correlated significantly with head size. 274 Markov Chain Monte Carlo (MCMC) multivariate generalised linear mixed models where 275 used for assessing the continuous effects of parental age (hatch year) on telomere length and 276 telomere length dynamics. Repeatabilites were calculated using R package rptR (Stoffel et al., 
277 2017). Heritabilities were obtained using one-way ANOVA from the full sib design and (for

278 the models including parental age and treatment effects) using generalised linear mixed

279 models for the repeated measures design ( $\mathrm{R}$ package MCMCglmm) (Hadfield 2010, de

280 Villemereuil, Morrissey, Nakagawa \& Schielzeth, 2018; Kuznetsova \& Hadfield, 2010). The

281 models were run for both telomere measurements (first and second) as well as change as a

282 dependent variable. The models included parent nest as random effect and the same fixed

283 effects as the repeated measures mixed model for the effect of telomere length change. Both

284 repeatability and heritability measures are reported together with $95 \%$ coefficient intervals

285 (CI). The distribution of the traits was normal or close to normal distribution (Figures S1-S3),

286 accordingly, models were ran with untransformed values. Power analyses were conducted

287 based on Monte Carlo simulations (Green \& MacLeod, 2015) (Table S3). The R code for

288 different steps in the statistical analyses is accessible from the data repository (Sepp et al.

289 2021).

290

291 Results

292 There were no significant effects of the ages of the natal or foster parents on offspring 293 telomeres at hatching or the change in offspring telomere length from hatching to the end of 294 post-natal development, neither for male nor for female chicks (Figure 1, see Tables 2 and S2 295 for results with age groups, young vs old, and Tables 3 and S1 for results with parental age as 296 a continuous factor). Parental age effect did not become significant after removal of the non297 significant interactions and chick sex from the model (Table S2). When we entered the 298 parental age squared in the models, it did not change this result (Tables S7-S9). Telomere 299 length was individually repeatable between the first and second sampling, separated by on 
average 11 days (repeatability $\mathrm{r}=0.55, \mathrm{CI}=0.368$ to $0.69, \mathrm{p}<0.0001$, Figure 2 ). Chick telomere length between the first and second telomere measurements increased rather than decreased (the estimated change in relative telomere length was $0.08 \pm 0.05, \mathrm{p}=0.003$, Table 2 ; when one outlier chick with highest increase in telomere length was removed, the results stayed similar, estimated change $0.06 \pm 0.04, \mathrm{p}=0.005)$. The rate of growth during post-natal development was not significantly related to the change in telomere length (measured as change of head size, $r<0.0001 ; p=0.97$, Figure 3). Chick growth rate was not related to the age of the parents and foster parents (all parental effect p-values $>0.31$, Tables S4-S5). The power for detecting potential effects of parental age on telomere length and telomere shortening in our sample is reported in Table S3. The study set up also allowed us to assess wide-sense heritability of telomere length, although these results must be taken with caution, since we did not use a split nest cross-fostering design. Chick telomere length at both first $\left(\mathrm{h}^{2}=0.27 \mathrm{CI}=0.05\right.$ to 0.50$)$ and second $\left(\mathrm{h}^{2}=0.30 \mathrm{CI}=0.08\right.$ to 0.54$)$ measurement as well as the change of telomere length (calculated as telomere length 2 - telomere length $1, \mathrm{~h}^{2}=0.14$ $\mathrm{CI}=0.03$ to 0.29 ) were heritable.

\section{Discussion}

Parental age often has long-term consequences for offspring phenotype and fitness, but the mechanisms that mediate these effects remain insufficiently studied. Previous research suggest that telomeres may be an important mechanism mediating these effects, but the routes by which these effects occur are not well understood. The cross-fostering experiment used here allowed us to distinguish whether any effects of parental age on offspring telomeres occur as a result of epigenetic like and/or pre-natal effects vs. post-natal effects. Previous research in this 
323 colony of common gulls has demonstrated that offspring fitness decreases with increasing 324 parental age: recruitment rate decreases in common gulls after the 10th breeding year (12-13 325 years of age) (Rattiste, 2004), and older gulls allocate less nutrients to their eggs (Urvik et al., 326 2018). However, despite these demonstrated effects of parental age on offspring fitness in this 327 species, we did not find any evidence of the effect of parental age on offspring telomeres at 328 hatching or the change in telomere length during post-natal development.

329 Although parental age has been shown to have both negative and positive effects on offspring 330 telomere length (Table 4), this has not been found in all studies. For example, no effect of 331 parental age on offspring telomere length was found in a study of Soay sheep (Ovis aries) 332 despite a large sample size (Froy et al., 2017). Although bird studies have generally found a 333 negative effect of parental age on offspring telomeres (see for example studies in alpine swifts, 334 (Criscuolo et al., 2017), and European shags Phalacrocorax aristotelis, (Heidinger et al., 335 2016), this is not a universal pattern (for example, older great reed warbles Acrocephalus 336 arundinaceus produced offspring with longer telomeres, (Asghar et al., 2015b). Also in 337 humans the effect of paternal age is positive rather than negative, as older fathers sire 338 offspring with longer telomeres (Broer et al., 2013). A review article summarizing these 339 results concluded that while there is no clear pattern across species, this is unlikely to be 340 explained by statistical noise or publication bias (Eisenberg, 2014), but rather linked to the 341 specific biology of each species. There are also several additional factors that could contribute 342 to these mixed results: whether the study is experimental or correlative, at what age the 343 offspring are sampled, and whether it is a longitudinal versus cross-sectional study of parental 344 age. Accordingly, we cannot rule out that a longitudinal set-up would have revealed an effect 345 of parental age on offspring telomere results also in our study system, as the cross-sectional 
346 design could have obscures the within individual patterns. Another possibility is that the link 347 between parental age and offspirng telomere length in this species was too weak to be revealed 348 from our sample size, despite relatively good test power (Table S3). In this case, and also in 349 the case of no effect of parental age, it is possible that telomere length in common gulls is 350 indeed relatively buffered from environmental influence.

351 Another possibility is that our experimental time scale (approximately two weeks) was too 352 short to detect effects on telomeres. However, as the maximum lifespan of red blood cells of 353 birds is estimated to be 30-45 days (Rodnan, Ebaugh \& Fox 1957), we should have been able 354 to detect telomere loss if it took place. Indeed, several studies have detected telomere loss 355 within 30 days or less (e.g. Foote et al., 2011, Boonekamp et al., 2014; Heidinger et al., 2016). 356 We also considered the possibility that selective dissappearance played a role in our finding of 357 a lack of parental age effect on offspring telomere length and shortening, but consider it 358 unlikely. The probability of trapping chicks from old and young parents did not differ 359 statistically significantly. During the early age, recapture rate mainly depends on nest location $360-$ it is more difficult to trap chicks from nests that are close to water or surrounded by dense 361 vegetation. In our colony, about half of the chicks die before fledging, mainly due to common 362 hazards of the environment. Parental care quality might play a small role in chick mortality, 363 but it is very likely that this role is eclipsed by the effect of random mortality. Accordingly, we 364 consider the role of selective dissappearance to be negligible in our results.

365 Telomere length was repeatable across the chick rearing period in our study, indicating a 366 possible increase during post-natal development, and not being related to chick growth rate. 367 Telomeres were longer at the second sampling, when chicks were approximately 11 days old. 368 This period covered the fastest growth period of gull chicks. While telomeres shorten during 
371 (reviewed by Larsson, Rattiste, \& Lilleleht, 1997, Monaghan \& Haussmann, 2006). In several

growth in most studied adult vertebrates (which, as of now, mainly include mammals and some bird species), some vertebrates show increased telomerase activity during development bird species, telomerase activity appears to be highest in the hatchling age-class, when the proliferative demands of most organs are the highest (Haussmann, Winkler, Huntington, Nisbet \& Vleck, 2007). It has even been suggested that in free-living long-lived organisms, evolution should favour mechanisms that maintain the longest possible telomeres at the end of the most active growth period (Chan, \& Blackburn, 2004). Studies in the wild have shown that telomeres elongate in at least some life stages in Seychelles warblers (Acrocephalus sechellensis (Spurgin et al., 2018)), edible dormouse (Glis glis (Hoelzl et al., 2016)), Soay sheep (Fairlie et al., 2016), Magellanic penguins (Spheniscus magellanicus (Cerchiara et al., 2017)), and Atlantic salmon (Salmo salar (McLennan et al., 2018)). However, when looking at the few studies on species more closely related to common gulls, telomere shortening during the early growth period has been reported. For example, in lesser black-backed gull (Larus fuscus), telomeres shortened from hatching to ten-days old (Foote et al., 2011), and in blacktailed gull chicks (Larus crassirostris), telomere attrition was shown for chicks growing with siblings in the nest (but not singleton chicks (Mizutani, Niizuma, \& Yoda, 2016)). The latter study suggests that, in favourable growing conditions, telomere attrition might be prevented. However, more results on closely related species are needed to confirm the possibility of telomere lengthening during early growth in gulls. Growth rate was independent of telomere length or telomere dynamics (Figure 3). In general, a trade-off between rapid growth and telomere maintenance is expected, due to increased number of cell divisions required to attain larger size, and/or increased loss of telomere length during each cell division as a consequence 
392 of the conditions required for fast growth (e.g. higher metabolic rate and ROS production 393 reviewed by Monaghan \& Ozanne (2018)). The current study adds to the increasing number of 394 studies suggesting a different pattern in long-lived seabirds (Mizutani et al., 2016; Young et 395 al., 2017). Seabirds are distinguished from most other species by a long time period between 396 the end of relatively fast somatic growth and the beginning of reproduction (stretching several 397 years). More studies applying comparable methodological approaches are needed for a 398 comparative study, including patterns of growth and life-history strategies of different species 399 to determine if this phenomenon of delayed reproduction is causally linked with the lack of an 400 association between fast growth and telomere shortening in seabirds.

401 In conclusion, our results suggest that the age of the parents at the time of offspring 402 conception does not influence offspring telomere length or the change in telomere length in 403 common gulls. The physiological mechanism mediating the link between parental age and 404 recruitment rate in common gulls remains therefore open and deserves further attention. An 405 important area of future research is to identify other mechanisms that mediate the long-term 406 effects of parental age on offspring and to better understand the factors that contribute to the 407 variation in the influence of parental age on offspring telomeres across species. Future studies 408 applying this design should also consider measuring parental telomere length, to understand if 409 telomere length is inherited to the offsprings in a parental-age-independent manner. 410 Additionally, studies testing the same hypothesis over years with different breeding conditions 411 could indicate how much the links between parental age and offspring quality are dependent 412 on environmental conditions. 
416 We thank Mari-Ann Lind, Ulvi Karu, and other field assistants. We thank three anonymous

417 reviewers who gave valuable suggestions for improving the manuscript.

419 Funding

420 This work was supported by the Estonian Research Council (IUT21-1, IUT34-8, PSG458, 421 PSG653), Marie Sklodowska-Curie grant agreement no. 701747 to TS, and Mobilitas Pluss 422 from European Regional Development Fund (MOBJD344 to KN).

423

424 Compliance with ethical standards

425 The experimental protocol was approved by the Ministry of Rural Affairs of the Republic of 426 Estonia (licence no. 106, issued 24.05.2017) and was performed in accordance with relevant 427 Estonian and European guidelines and regulations.

428

\section{Conflict of interests}

430 The authors declare no competing interests.

\section{Authors' contribution}

433 TS, MG, PH and KN conceived the ideas and designed methodology; JU, KR, RM and LS 434 collected the data; KR provided demographic data; TS, BH, JK and MG analysed the samples; $435 \mathrm{PH}, \mathrm{RM}$ and TS performed statistical analyses. All authors contributed critically to the drafts 436 and gave final approval for publication. 
Data accessibility

Data available from the Dryad Digital Repository (TBA)

440

441

442

443

444

445

446

447

448

449

450

451

452

453

454

455

456

457

458

459

460

461

462

463

464

465

466

467

468

469

470

471

472

473

474

475

476

477

478

479

480

\section{References}

Asghar, M., Bensch, S., Tarka, M., Hansson, B., \& Hasselquist, B. (2015a). Maternal and genetic factors determine early life telomere length. Proceedings of the Royal Society B: Biological Sciences, 282 20142263. doi: 10.1098/rspb.2014.2263

Asghar, M., Hasselquist, D., Hansson, B., Zehtindjiev, P., Westerdahl, H., \& Bensch, S. (2015 b). Hidden costs of infection: Chronic malaria accelerates telomere degradation and senescence in wild birds. Science 347(6220), 436-438.

Bateson, M. \& Nettle, D. (2017). The telomere lengthening conundrum - it could be biology. Aging Cell 16, 312-319 (2017).

Bauch, C., Boonekamp, J. J., Korsten, P., Mulder, E., \& Verhulst, S. (2019). Epigenetic inheritance of telomere length in wild birds. PLoS Genetics. 15, e1007827 (2019).

Beamonte-Barrientos, R., Velando, A., Drummond, H. \& Torres, R. Senescence of maternal effects: aging influences egg quality and rearing capacities of a long-lived bird. American Naturalist 175, 469-480 (2010).

Blackburn, E. H. (1991). Structure and function of telomeres. Nature 350, 569-573.

Bock, M. J., Jarvis, G. C., Corey, E. L. Stone, E. E. \& Gribble, K.E. (2019). Maternal age alters offspring lifespan, fitness, and lifespan extension under caloric restriction. Scientific Reports 9, 3138.

Boonekamp, J. J., Mulder, G. A., Salomons, H. M., Dijkstra, C., Verhulst, S. (2014) Nestling telomere shortening, but not telomere length, reflects developmental stress and predicts survival in wild birds. Proceedings of the Royal Society B: Biological Sciences, 281: 20133287. https://doi.org/10.1098/rspb.2013.3287.

Bouwhuis, S., Verhulst, S., Bauch, C. \& Vedder, O. (2018) Reduced telomere length in offspring of old fathers in a longlived seabird. Biology Letters, 14, 20180213.

Bowers, E. K., Sakaluk, S. K., \& Thompson, C. F. (2017). Interactive effects of parental age on offspring fitness and age-assortative mating in a wild bird. Journal of experimental zoology. Part A, Ecological and integrative physiology, 327, 302-310. https://doi.org/10.1002/jez.2090

Bradley R. J., \& Safran, R. J. (2014). Conceptual revision and synthesis of proximate factors associated with age-related improvement in reproduction. Ethology, 120, 1-16.

Broer, L., Codd, V., Nyholt, D. R., Deelen, J., Mangino, M., Willemsen, G. ... Boomsma, D.I. (2013). Meta-analysis of telomere length in 19,713 subjects reveals high heritability, stronger maternal inheritance and a paternal age effect. European Journal of Human Genetics 21, 1163-1168.

Bukacinska, M., Bukacinski, D., Epplen, J. T., Sauer, K. P., \& Lubjuhn, T. (1998). Low frequency of extra-pair paternity in common gulls (Larus canus) as revealed by DNA fingerprinting. Journal of Ornithology 139, 413-420 (1998).

Carslake, D., Tynelius, P., van den Berg, G. J., \& Smith, G. D. (2019). Associations of parental age with offspring all-cause and cause-specific adult mortality. Scientific Reports, 9, 17097. https://doi.org/10.1038/s41598-019-52853-8 
Cerchiara, J. A., Risques, R. A., Prunkard, D., Smith, J. R., Kane, O. J., 1 \& Boersma, P. D. (2017). Telomeres shorten and then lengthen before fledging in Magellanic penguins (Spheniscus magellanicus). Aging 9, 487-493.

Chan, S. R. \& Blackburn, E. H. (2004). Telomeres and telomerase. Philosophical Transactions of the Royal Society B: Biological Sciences 359. 109-121.

Clutton-Brock, T. H. (1984). Reproductive Effort and Terminal Investment in Iteroparous Animals The American Naturalist, 123, 212-229.

Cong, Y. S., Wright, W. E. \& Shay, J. W. Human telomerase and its regulation. Microbiol. Mol. Biol. Rev. 66, 407 (2002).

Cawthon, R. M. Telomere measurment by quantitative PCR. Nucleic Acids Res. 129, 550-557 (2002).

Criscuolo, F., Zahn, S., \& Bize, P. (2017) Offspring telomere length in the long lived Alpine swift is negatively related to the age of their biological father and foster mother. Biology Letters, 13, 20170188.

Dagnall, C. L., Hicks, B., Teshome, K., Hutchinson, A. A., Gadalla, S. M., Khincha, P. P. ... Savage, S. A. (2017). Effect of pre-analytic variables on the reproducibility of qPCR relative telomere length measurement. PloS One, 12, e0184098.

Dantzer, B., van Kesteren, F., Westrick, S. E., Boutin, S., McAdam, A. G., Lane, J. E., ... Pat Monaghan. (2020). Maternal glucocorticoids promote offspring growth without inducing oxidative stress or shortening telomeres in wild red squirrels. Journal of Experimental Biology 2020 223: jeb212373 doi: 10.1242/jeb.212373 Published 6 January 2020

de Frutos, C., López-Cardona A.P., Fonseca Balvís, N., Laguna-Barraza, R., Rizos, D., Gutierrez-Adán, A., \& Bermejo-Álvarez, P. (2016) Spermatozoa telomeres determine telomere length in early embryos and offspring. Reproduction, 151, 1-7.

de Villemereuil, P., Morrissey, M. B., Nakagawa, S., \& Schielzeth, H. (2018). Fixed-effect variance and the estimation of repeatabilities and heritabilities: issues and solutions. Journal of Evolutionary Biology, 31, 621-632.

Dugdale, H. L., \& Richardson, D. S. (2018). Heritability of telomere variation: it is all about the environment! Philosophical Transactions of the Royal Society B: Biological Sciences 373, 20160450.

Dupont, S. M., Barbraud, C., Chastel, O., Delord, K., Ruault, S., Weimerskirch,H. \& Angelier, F. (2018). Young parents produce offspring with short telomeres: A study in a long-lived bird, the Black-browed Albatross (Thalassarche melanophrys). PLoS ONE, 13, e0193526.

Eisenberg, D. T. A., \& Kuzawa, C. W. (2018). The paternal age at conception effect on offspring telomere length: mechanistic, comparative and adaptive perspectives. Philosophical Transactions of the Royal Society B: Biological Sciences 373, 20160442.

Eisenberg, D.T.A. Tackney, J., Cawthon, R.M., Cloutier, C.T. \& Hawkes, K. (2016). Paternal and grandpaternal ages at conception and descendant telomere lengths in chimpanzees and humans. American Journal of Physical Anthropology, 162, 201-207.

Eisenberg, D.T.A. (2014). Inconsistent inheritance of telomere length (TL): is offspring TL more strongly correlated with maternal or paternal TL? European Journal of Human Genetics 22, 8-9.

Fairlie, J., Holland, R., Pilkington, J. G., Pemberton, J. M., Harrington, L., \& Nussey, D. H. (2016). Lifelong leukocyte telomere dynamics and survival in a free-living mammal. Aging Cell, 15, 140-148. 
Foote, C. G. Gault, E. A., Nasir, L., \& Monaghan, P. (2011). Telomere dynamics in relation to early growth conditions in the wild in the lesser black-backed gull. Journal of Zoology, 283, 203-209.

Fridolfsson, A.K., Ellegren, E. 1999. A simple and universal method for molecular sexing of non-ratite birds. Journal of Avian Biology 30, 116-121.

Froy, H., Bird, E. J., Wilbourn, R. V., Fairlie, J., Underwood, S. L., Salvo-Chirnside, E., ... Nussey, D. H. (2017). No evidence for parental age effects on offspring leukocyte telomere length in free-living Soay sheep. Scientific Reports 7, 9991.

Giraudeau, M., Angelier, F., \& Sepp, T. (2019). Do telomeres influence pace- of- life- strategies in response to environmental conditions over a lifetime and between generations? BioEssays 41, 1800162.

Gomes, N. M. V, Ryder, O.A., Houck, M.L., Charter, S.J., Walker, W., Forsyth N.R., ... Wright W.E. (2011). Comparative biology of mammalian telomeres: hypotheses on ancestral states and the roles of telomeres in longevity determination. Aging Cell 10, 761-768.

Green, P., MacLeod, C. (2015). SIMR: an R package for power analysis of generalized linear mixed models by simulation. Methods in Ecology and Evolution, 7, 493-498.

Hadfield, J. D. (2010). MCMC Methods for Multi-Response Generalized Linear Mixed Models: The MCMCglmm R Package. Journal of Statistical Software, 33, 1-22.

Haussmann, M.F., Winkler, D.W., Huntington, C.E., Nisbet, I.C. \& Vleck, C.M. (2007) Telomerase activity is maintained throughout the lifespan of long-lived birds. Experimental Gerontology, 42, 610-618.

Haussmann, M. F., \& Heidinger, B. J. (2015). Telomere dynamics may link stress exposure and ageing across generations. Biology Letters 11, 20150396.

Heidinger, B.J., Herborn K. A., Granroth- Wilding H. M.V., Boner, W., Burthe, S., Newell, M., ... Monaghan, P. (2016) Parental age influences offspring telomere loss. Functional Ecology, 30, 1531-1538.

Hoelzl, F., Smith, S., Cornilsv, J.S., Aydinonat, D., Bieber, D., \& Ruf, T. (2016) Telomeres are elongated in older individuals in a hibernating rodent, the edible dormouse (Glis glis). Scientific Reports, 6, 36856.

Horn, T., Robertson, B.C., Will, M., Eason, D.K., Elliott, G.P. \& Gemmell, N.J. (2011). Inheritance of telomere length in a bird. PLOS ONE 6: e17199.

Kimura, M., Cherkas, L. F., Kato, B. S., Demissie, S., Hjelmborg, J. B., Brimacombe, M., ... Aviv, A. (2008). Offspring's leukocyte telomere length, paternal age, and telomere elongation in sperm. PLoS Genetics 4, e37.

Kinugawa, C., Murakami, T., Okamura K. \& Yajima. A. (2000). Telomerase activity in normal ovaries and premature ovarian failure. Tohoku Journal of Experimental Medicine, 190, 231-238.

Kuznetsova, A., Brockhoff, P.B. \& Christensen, R. B. H. (2017). LmerTest Package: Tests in Linear Mixed Effects Models. Journal of Statistical Software, 82, 1-26.

Larsson, K., Rattiste, K. \& Lilleleht, V. (1997). Heritability of head size in the common gull Larus canus in relation to environmental conditions during offspring growth. Heredity, 79, 201-20

Maklakov, A.A., \& Chapman, T. (2019). Evolution of ageing as a tangle of trade-offs: energy versus function. Proceedings of the Royal Society B: Biological Sciences, 286, 20191604. 
McLennan, D. Armstrong, J.D., Stewart, D.C., Mckelvey, S., Boner, W., Monaghan, P., Metcalfe, N.B. (2016). Interactions between parental traits, environmental harshness and growth rate in determining telomere length in wild juvenile salmon. Molecular Ecology, 25, 5425-5438.

McLennan, D., Armstrong, J. D., Stewart, D. C., Mckelvey, S., Boner, W., Monaghan, P., \& Metcalfe, N. B. (2018). Telomere elongation during early development is independent of environmental temperatures in Atlantic salmon. Journal of Experimental Biology, 221, 178616.

Mizutani, Y., Niizuma, Y., \& Yoda, K. (2016). How do growth and sibling competition affect telomere dynamics in the first month of life of long-lived seabird? PLoS ONE, 11, e0167261.

Monaghan, P., \& Ozanne, S. E. (2018). Somatic growth and telomere dynamics in vertebrates: relationships, mechanisms and consequences. Philosophical Transactions of the Royal Society B: Biological Sciences, 373, 20160446.

Monaghan, P. (2010). Telomeres and life histories: the long and the short of it. Annals of the New York Academy of Sciences, 1206, 130-142.

Monaghan, P. \& Haussmann, M.F. (2006). Do telomere dynamics link lifestyle and lifespan? Trends in Ecology and Evolution, 21, 47-53.

Nawrot, T.S., Staessen, J.A., Gardner, J.P. \& Aviv, A. (2004). Telomere length and possible link to X chromosome. Lancet, 363, 507-510.

Nettle, D., Monaghan, P., Gillespie, R., Brilot, B., Bedford, T., \& Bateson, M. (2015). An experimental demonstration that early-life competitive disadvantage accelerates telomere loss. Proceedings of the Royal Society B: Biological Sciences, 282, 20141610.

Njajou, O.T., Cawthon, R.M., Damcott, C.M., Wu, S.H., Ott, S., Garant, M.J., Blackburn, E.H., Mitchell, B.D., Shuldiner, A.R. \& Hsueh, W.-C. (2007). Telomere length is paternally inherited and is associated with parental lifespan. Proceedings of the National Academy of Sciences of USA 104, 12135-12139.

Noguera, J. C., \& Velando, A. (2020). Gull chicks grow faster but lose telomeres when prenatal cues mismatch the real presence of sibling competitors. Proceedings of the Royal Society B: Biological Sciences, 287, 20200242

Noguera, J. C., Metcalfe, N. B. \& Monaghan, P. (2018). Experimental demonstration that offspring fathered by old males have shorter telomeres and reduced lifespans. Proceedings of the Royal Society B: Biological Sciences, 285, 1874.

Nordfjäll, K., Larefalk, A., Lindgren, P., Holmberg, D. \& Roos, G . (2005). Telomere length and heredity: Indications of paternal inheritance. Proceedings of the National Academy of Sciences of USA, 102, 16374-16378.

Nussey, D. H., Baird, D., Barrett, E., Boner, W., Fairlie, J., Gemmell, N. ... Monaghan, P. (2014). Measuring telomere length and telomere dynamics in evolutionary biology and ecology. Methods in Ecology and Evolution, 5, 299-310.

Nussey, D. H., Froy, H., Lemaitre, J.-F., Gaillard, J. M., \& Austad, S. N. (2013). Senescence in natural populations of animals: widespread evidence and its implications for biogerontology. Ageing Research Reviews, 12, 214-225.

Olsson, M., Pauliny, A., Wapstra, E., Uller, T., Schwartz, T.\& Blomqvist, D . (2011). Sex differences in sand lizard telomere inheritance: paternal epigenetic effects increases telomere heritability and offspring survival. PLOS ONE 6: e17473. 
Rattiste, K., Klandorf, K., Urvik, J., Sepp, T., Asghar, M. Hasselquist, D., Cooey, C., \& Hrõak, P. (2015). Skin pentosidine and telomere length do not covary with age in a longlived seabird. Biogerontology, 16, 435-441.

Rattiste, K. (2004). Reproductive success in presenescent common gulls (Larus canus): the importance of the last year of life. Proceedings of the Royal Society B: Biological Sciences, 271, 2059-2064.

Reichert, S., Rojas, E., Zahn, S., Robin, J.-P., Criscuolo, F. \& Massemin, S. (2015) Maternal telomere length inheritance in the king penguin. Heredity, 114, 10-16.

Ricklefs, R. E. Insights from comparative analyses of aging in birds and mammals. Aging cell, 9, 273-284 (2009).

Rodnan, G. P., Ebaugh, Jr. F.G., Spivey Fox, M. R. \& Chambers, D.M. (1957). the life span of the red blood cell and the red blood cell volume in the chicken, pigeon and duck as estimated by the use of $\mathrm{Na} 2 \mathrm{Cr} 51 \mathrm{O} 4$ : with observations on red cell turnover rate in the mammal, bird and reptile. Blood, 124, 355-366.

Sepp, T., Meitern, R., Heidinger, B., Noreikiene, K., Rattiste, K., Hõrak, P. saks, L., Urvik, J., Giraudeau, M. (2021). Supplementary data for the article: Parental age does not influence offspring telomeres during early life in common gulls (Larus canus) (Version 0.1) [Data set]. Molecular Ecology. Zenodo. http://doi.org/10.5281/zenodo.4485871

Sepp, T., Rattiste K., Saks, L., Meitern, R., Urvik, J., Kaasik, A., \& Hõrak, P. (2017). A small badge of longevity: opposing survival selection on the size of white and black wing markings. Ournal of Avian Biology, 48, 570-580.

Simons, M. J., Stulp, G. \& Nakagawa, S. (2014). A statistical approach to distinguish telomere elongation from error in longitudinal datasets. Biogerontology ,15, 99-103.

Spurgin, L. G., Bebbington, K., Fairfield, E. A., Hammers, M., Komdeur, J., Burke, T. ... Richardson, D. S. (2018). Spatio-temporal variation in lifelong telomere dynamics in a long-term ecological study. Journal of Animal Ecology, 87, 187-198.

Stearns, S. C. (1992). The evolution of life-histories, Oxford University Press.

Stier, A., Metcalfe, N. B., \& Monaghan, P. (2019). Ageing before birth: pace and stability of prenatal growth affect telomere dynamics. bioRxiv, 809087. doi: https://doi.org/10.1101/809087

Stoffel, M. A., Nakagawa, S., \& Schielzeth H. (2017). RptR: Repeatability estimation and variance decomposition by generalized linear mixed-effects models. Methods in Ecology and Evolution, 8, 1639-1644.

Tarry-Adkins, J. L., Chen, J. H., Smith, N. S., Jones, R. H., Cherif, H. \& Ozanne, S.E. (2009). Poor maternal nutrition followed by accelerated postnatal growth leads to telomere shortening and increased markers of cell senescence in rat islets. The FASEB Journal, 23, 152-1528.

Torres, R., Drummond, H., \& Velando, A. (2011). Parental age and lifespan influence offspring recruitment: a long-term study in a seabird. PloS ONE, 6, e2724.

Unryn, B. M., Cook, L. S. \& Riabowol, K. T. (2005). Paternal age is positively linked to telomere length of children. Aging Cell, 4, 97-101.

Urvik, J., Rattiste, K., Giraudeau, M., Okuliarová, M., Hõrak, P., \& Sepp, T. (2018) Agespecific patterns of maternal investment in common gull egg yolk. Biology Letters, 14, 20180346.

Velarde, M., \& Menon, R. (2016). Positive and negative effects of cellular senescence during female reproductive aging and pregnancy, Journal of Endocrinology, 230, R59-R76. 
677

Viblanc, V. A., Schull, Q., Stier, A., Durand, L., Lefol, E., Robin, J-P. ... Criscuolo, F.(2020). Foster rather than biological parental telomere length predicts offspring survival and telomere length in king penguins. Molecular Ecology, Wiley, 2020, ff10.1111/mec.15485ff. ffhal-02868474f.

Young, A. J. (2018). The role of telomeres in the mechanisms and evolution of life-history trade-offs and ageing. Philosophical Transactions of the Royal Society B: Biological Sciences, 373, 20160452.

Young, R. C., Welcker, J., Barger, C. P., Hatch, S. A., Merkling T., Kitaiskaia, E. V. ... Kitaysky, A. S. (2017). Effects of developmental conditions on growth, stress and telomeres in black-legged kittiwake chicks. Molecular Ecology, 26, 3572-3584.

\section{Tables and figures}

Table 1. Cross-fostering experiment sample sizes. A total of 72 chicks from 40 nests were included in the experiment.

\begin{tabular}{llll}
\hline Parent gender & Manipulation & $\begin{array}{l}\text { Number } \\
\text { of nests }\end{array}$ & $\begin{array}{l}\text { Number } \\
\text { of chicks }\end{array}$ \\
\hline Female & Young to young & 10 & 12 \\
& Old to old & 10 & 18 \\
\multirow{4}{*}{ Male } & Young to old & 10 & 26 \\
& Old to young & 10 & 16 \\
& Young to young & 8 & 14 \\
& Old to old & 12 & 18 \\
& Young to old & 11 & 24 \\
& Old to young & 9 & 16 \\
\hline
\end{tabular}

Table 2. Repeated measures mixed model of telomere length dynamics (separate models for mother and father age groups). Final models without non-significant interactions are presented in supplementary materials (Table S2).

\begin{tabular}{lcccccc}
\hline Predictor & Estimates & $C I$ & $p$ & Estimates & $C I$ & $p$ \\
\hline $\begin{array}{l}\text { second - first } \\
\text { measurement }\end{array}$ & 0.11 & $0.02-0.20$ & $\mathbf{0 . 0 2 2}$ & 0.09 & $-0.01-$ & 0.066 \\
& & & & & 0.18 & \\
chick sex & -0.02 & $-012-009$ & $\mathbf{0 . 7 4 9}$ & -0.01 & $-0.11-$ & 0.796 \\
& & & & & 0.09 & \\
mother age group & 0.04 & $-0.10-0.17$ & 0.592 & & & \\
$\begin{array}{l}\text { foster mother age } \\
\text { group }\end{array}$ & 0.11 & $-0.02-0.25$ & 0.099 & & & \\
$\begin{array}{l}\text { time * mother age } \\
\text { group }\end{array}$ & -0.03 & $-0.14-0.08$ & 0.550 & & &
\end{tabular}




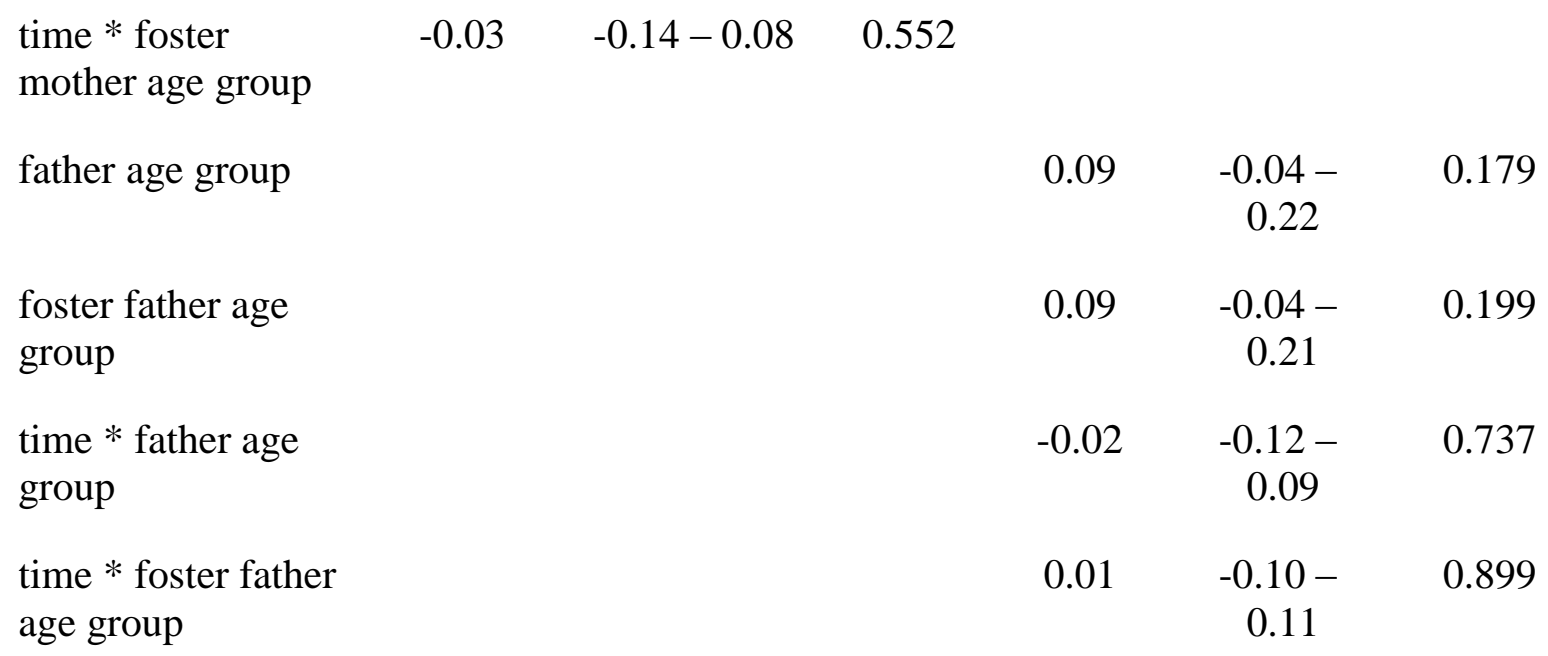

\section{Random Effects}

$\begin{array}{lll}\sigma^{2} & 0.03 & 0.03 \\ \tau_{00} & 0.02 \text { chick_ID:parent_nest } & 0.02 \text { chick_ID:parent_nest } \\ & 0.02 \text { parent_nest } & 0.01 \text { parent_nest } \\ \text { ICC } & 0.59 & 0.58 \\ \mathrm{~N} & 72 \text { chick_ID } & 72 \text { chick_ID } \\ & 40 \text { parent_nest } & 40 \text { parent_nest }\end{array}$

Observations

144

144

Table 3. Markov Chain Monte Carlo (MCMC) multivariate generalised linear mixed models of parental age (hatch year) effects on telomere length and telomere length dynamics.

$\begin{array}{llllll}\begin{array}{l}\text { Mother's } \\ \text { hatch year }\end{array} & \begin{array}{l}\text { Foster } \\ \text { mother's } \\ \text { hatch year }\end{array} & \begin{array}{l}\text { Random } \\ \text { effect } \\ \text { (parent } \\ \text { nest) }\end{array} & \begin{array}{l}\text { Father's } \\ \text { hatch year }\end{array} & \begin{array}{l}\text { Foster } \\ \text { father's } \\ \text { hatch year }\end{array} & \begin{array}{l}\text { Random } \\ \text { effect } \\ \text { (parent } \\ \text { nest) }\end{array}\end{array}$

\section{Telomere length at hatching}

$\begin{array}{rcccccc}\text { Mean }(95 \% & 0.004(- & 0.007(- & 0.016 & 0.006(- & 0.006(- & 0.016 \\ \text { CI) } & 0.005- & 0.001- & (0.003- & 0.003- & 0.004- & (0.003- \\ & 0.012) & 0.015) & 0.032) & 0.015 & 0.016) & 0.032) \\ \text { pMCMC } & 0.41 & 0.10 & & 0.23 & 0.25 & \end{array}$

\section{Telomere length at second trapping}

\begin{tabular}{ccccccc} 
Mean $(95 \%$ & $0.001(-$ & $0.003(-$ & 0.021 & $0.009(-$ & $0.009(-$ & 0.019 \\
& $0.010-$ & $0.007-$ & $(0.004-$ & $0.002-$ & $0.003-$ & $(0.004-$ \\
\hline
\end{tabular}




\begin{tabular}{rcccccc}
\hline CI) & $0.014)$ & $0.014)$ & $0.043)$ & $0.020)$ & $0.020)$ & $0.039)$ \\
pMCMC & 0.85 & 0.56 & & 0.11 & 0.16 & \\
Change of telomere length & & & & & \\
Mean (95\% & $-0.003(-$ & $-0.005(-$ & 0.011 & $-0.031(-$ & $0.001(-$ & 0.011 \\
CI) & $0.013-$ & $0.014-$ & $(0.002-$ & $0.174-$ & $0.01-$ & $(0.002-$ \\
& $0.006)$ & $0.005)$ & $0.023)$ & $0.103)$ & $0.012)$ & $0.023)$ \\
pMCMC & 0.50 & 0.33 & & 0.65 & 0.093 & \\
\hline
\end{tabular}

690 CI-confidence interval.

691 
693 Table 4. Overview of studies in non-human vertebrates (excluding also laboratory rodents) investigating the effect of parental age 694 on offspring telomere length. For a review on human studies, please see Froy et al (2017). Extended version of the table including 695 study design and offspring developmental stage available in Supplementary Materials (Table S10).

\begin{tabular}{|c|c|c|c|c|c|c|}
\hline Class & Species & Sample size & $\begin{array}{l}\text { Studied } \\
\text { parental } \\
\text { effects }\end{array}$ & $\begin{array}{l}\text { Telomere } \\
\text { method }\end{array}$ & $\begin{array}{l}\text { Parental age } \\
\text { effect }(-/+)\end{array}$ & 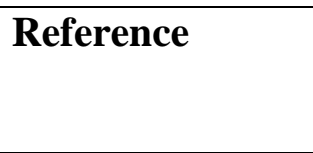 \\
\hline \multirow[t]{2}{*}{$\begin{array}{l}\text { Teleost } \\
\text { fish }\end{array}$} & \multirow{2}{*}{$\begin{array}{l}\text { Atlantic salmon } \\
\text { (Salmo salar) } \\
\text { Atlantic salmon } \\
(\text { Salmo salar })\end{array}$} & $84 \mathrm{HSF}$ & $\mathrm{M} \& \mathrm{P}$ & qPCR (RTL) & \multirow{2}{*}{$\begin{array}{l}\text { Complex } \\
\mathrm{P}_{\text {fry }}(+) \\
\text { Complex } \\
\mathrm{P}_{\text {fry }}(-)\end{array}$} & \multirow{2}{*}{$\begin{array}{l}\text { McLennan et al. } \\
2016 \\
\text { McLennan et al. } \\
2018\end{array}$} \\
\hline & & $60 \mathrm{HSF}$ & $M \& P$ & qPCR (RTL) & & \\
\hline Reptiles & $\begin{array}{l}\text { Sand lizard (Lacerta } \\
\text { agilis) }\end{array}$ & $\mathrm{N}_{\text {sons }}=12$ & $\mathrm{P}$ & $\begin{array}{l}\text { TRF (TL in } \\
\text { bp) }\end{array}$ & $\mathrm{P}_{\text {sons }}(-)$ & Olsson et al., 2011 \\
\hline \multirow[t]{6}{*}{ Birds } & $\begin{array}{l}\text { Great reed warbler } \\
\text { (Acrocephalus } \\
\text { arundinaceus) }\end{array}$ & $\begin{array}{l}\mathrm{N}_{\text {ind }}=139 \\
\mathrm{~N}_{\text {broods }}=46\end{array}$ & $M \& P$ & qPCR (RTL) & $\mathrm{M}(+)$ & $\begin{array}{l}\text { Ashgar et al., } \\
2015 \mathrm{a}\end{array}$ \\
\hline & European shag & $\mathrm{N}_{\text {ind }}=311$ & $M \& P$ & qPCR (RTL) & $\mathrm{M}_{\Delta \mathrm{RTLoffspring}}(-)$ & Noguera et al., \\
\hline & $\begin{array}{l}\text { (Phalacrocorax } \\
\text { aristotelis) }\end{array}$ & $\mathrm{N}_{\text {broods }}=134$ & & and $\Delta \mathrm{K} I \mathrm{~L}$ & $\mathrm{P}_{\Delta \mathrm{R} \text { TLoffspring }}(-)$ & \\
\hline & \multirow{2}{*}{$\begin{array}{l}\text { Alpine } \\
\text { melba) }\end{array}$} & $\mathrm{N}_{\text {ind }}=95$ & $M \& P$ & qPCR (RTL) & $\mathrm{P}_{\text {biological }}(-)$ & \multirow[t]{2}{*}{$\begin{array}{l}\text { Heidinger et al. } \\
2016\end{array}$} \\
\hline & & $\mathrm{N}_{\text {broods }}=54$ & $\begin{array}{l}\text { biological and } \\
\text { foster }\end{array}$ & & $\mathrm{M}_{\text {foster }}(-)$ & \\
\hline & $\begin{array}{l}\text { Zebra } \\
\text { (Taeniopygia } \\
\text { guttata) }\end{array}$ & $\begin{array}{l}\mathrm{N}_{\text {ind }}=139 \\
\mathrm{~N}_{\text {HSbroods }}=64\end{array}$ & $\mathrm{P}$ & qPCR (RTL) & $\mathrm{P}(-)$ & $\begin{array}{l}\text { Criscuolo et al., } \\
2017\end{array}$ \\
\hline
\end{tabular}




\begin{tabular}{|c|c|c|c|c|c|}
\hline $\begin{array}{l}\text { Black-browed } \\
\text { albatross } \\
\text { (Thalassarche } \\
\text { melanophrys) }\end{array}$ & $\mathrm{N}_{\text {ind }}=51$ & Mean M \& P & $\begin{array}{l}\mathrm{TRF} \\
\mathrm{bp})\end{array}$ & $\operatorname{Par}(+)$ & Dupont et al. 2018 \\
\hline $\begin{array}{l}\text { Common tern } \\
\text { (Sterna hirundo) }\end{array}$ & $\mathrm{N}=142$ & $M \& P$ & $\begin{array}{l}\text { TRF } \quad(\mathrm{TL} \text { in } \\
\mathrm{bp})\end{array}$ & $\mathrm{P}(-)$ & $\begin{array}{l}\text { Bouwhuis et al. } \\
2018\end{array}$ \\
\hline $\begin{array}{l}\text { Jackdaw } \quad \text { (Corvus } \\
\text { monedula) }\end{array}$ & $\begin{array}{l}\mathrm{N}_{\text {ind }}=715 \\
\mathrm{~N}_{\text {nests }}=298 \\
\mathrm{~N}_{\text {ind }}=61 \\
\mathrm{~N}_{\text {nests }}=31\end{array}$ & $\begin{array}{l}\text { M \& P } \\
\text { biological and } \\
\text { foster }\end{array}$ & $\begin{array}{l}\text { TRF } \quad(\mathrm{TL} \text { in } \\
\mathrm{bp})\end{array}$ & $\mathrm{P}_{\text {biol }}(-)$ & Bauch et al., 2019 \\
\hline $\begin{array}{l}\text { Common gull (Larus } \\
\text { canus) }\end{array}$ & $\begin{array}{l}\mathrm{N}_{\text {ind }}=72 \\
\mathrm{~N}_{\text {nests }}=40\end{array}$ & $M \& P$ & $\begin{array}{l}\text { qPCR }(\mathrm{RTL} \\
\text { and } \Delta \mathrm{RTL})\end{array}$ & No effect & $\begin{array}{l}\text { Sepp et al. (current } \\
\text { study) }\end{array}$ \\
\hline $\begin{array}{l}\text { Soay sheep (Ovis } \\
\text { aries) }\end{array}$ & $\mathrm{N}_{\text {ind }}=318$ & $M \& P$ & qPCR (RTL) & No effect & Froy et al. 2017 \\
\hline $\begin{array}{l}\text { Chimpanzee } \quad \text { (Pan } \\
\text { troglodytes) }\end{array}$ & $\mathrm{N}_{\text {ind }}=40$ & $\mathrm{P}$ & qPCR (RTL) & $\mathrm{P}(+)$ & $\begin{array}{l}\text { Eisenberg et al. } \\
2016\end{array}$ \\
\hline
\end{tabular}


696 Abbreviations: TL - telomere length, RTL - relative telomere length, TRF - terminal 697 restriction fragment, HSF - half sib families, ind - individuals, P - paternal age effect, M 698 maternal age effect, Par - parental age effect, (-) negative association, (+) positive association

699

700

701

702

703

704

705

706

707

708

709

710

711

712

713
Figure 1. Parents' and foster parents' age group did not affect offspring telomere length (A-B) and telomere dynamics (C-F). Mother's and father's age groups coincided for most, but not all chicks. Columns denote group means, whiskers are standard errors.

Figure 2. Telomere length was individually repeatable between first (avg. 0.61 days after hatching) and second blood sampling (avg. 10.62 days after hatching). $\mathrm{X}=\mathrm{Y}$ line is depicted to illustrate the direction of individual increase of telomere length.

Figure 3. Relative telomere length dynamics between the first and second sampling (average time difference 10.62 days) were not related to chick growth rate (change of head size). Since head size and telomere length were measured at the same time points for individual birds, time is not included as a factor here. 